dr hab. Zdzisław Gębotyś

Uniwersytet Kazimierza Wielkiego w Bydgoszczy

Katedra Informacji Naukowej i Bibliologii

zdzislaw.gebolys@ukw.edu.pl

\title{
ETYCZNE ASPEKTY SPONSORINGU I FUNDRAISINGU BIBLIOTECZNEGO (WYCHODZĄC OD LADEWIGA)
}

\author{
THE ETHICAL ASPECT OF THE LIBRARY \\ SPONSORING AND FUNDRAISING \\ (STARTING FROM LADEWIG)
}

\begin{abstract}
Abstrakt
„Dary budują przyjaźń - w bibliotekach ofiarodawców”. Myśl Paula Ladewiga, wybitnego bibliotekarza i bibliotekoznawcy niemieckiego stanowi punkt wyjścia do ogólniejszych rozważań nad etyczną stroną współczesnego bibliotecznego fundraisingu i sponsoringu. Celem tekstu jest przegląd podstawowych czynników determinujących sponsoring i fundraising biblioteczny oraz określenie ich etycznego wymiaru w praktyce bibliotecznej. W wyborze sponsora i/lub fundraisera dla biblioteki, biblioteka musi ważyć racje i interesy, kierując się, z jednej strony, troską o byt, a z drugiej strony, bacząc o swoje dobre imię (wizerunek). Pierwiastek etyczny można odnaleźć w każdym niemal z elementów sponsoringu i fundraisingu bibliotecznego: sponsor/fundraiser (kto); przedmiot sponsoringu/fundraisingu (co); miejsce sponsoringu/fundraisingu (gdzie); czas sponsoringu/fundraisingu (kiedy), powód sponsoringu/fundraisingu (dlaczego).
\end{abstract}

Słowa kluczowe: sponsoring, fundraising, biblioteka, etyka, Ladewig Paul.

\footnotetext{
Abstract

„Donations build friendship - in the benefactors' libraries”. The idea of Paul Ladewig - the prominent German librarian and library scientist, is a starting point for more general reflections on the ethical dilemmas
} 
of the fundraising and sponsoring at the present-day. The aim of this text is to look through the basic factors determining the sponsoring and fundraising for the libraries and to evaluate their ethical dimension in the library practice. A library, which aims to select a sponsor and/or a fundraiser, must take into the consideration both rations and business matters. It must on the one hand, be guided by the concern for the maintenance, and on the other hand - keep its good name. The ethical dilemma can be found in almost every component of the sponsoring and fundraising: a sponsor/fundraiser (who); a subject of sponsoring and fundraising (what); a space of the sponsoring/fundraising (where); a time of sponsoring/fundraising (when); a reason of sponsoring/ /fundraising (why).

Keywords: sponsoring, fundraising, library, ethics, Ladewig Paul.

\section{Wstęp}

Pecunia non olet - powszechnie znana łacińska maksyma, sięgająca czasów starożytnych, mogłaby być i bywa punktem wyjścia do rozważań nad etyczną stroną dobroczynności. Zważywszy jednak na wymowę tej sentencji oraz panujące w społeczeństwie normy i przekonania moralne, musielibyśmy sprowadzić dyskurs do poziomu rozważań na temat nieetycznych (czytaj także patologicznych) przypadków wiążących się z dobroczynnością. Dlatego też sięgnęliśmy po bliższą czasowo i o bardziej neutralnym wydźwięku myśl Paula Ladewiga ${ }^{1}$, wybitnego niemieckiego bibliotekarza i bibliotekoznawcy: „Dary budują przyjaźń w bibliotekach ofiarodawców”2. Traktujemy ją, nie jako dogmat, ale raczej punkt wyjścia do rozważań nad etyczną stroną sponsoringu i fundraisingu bibliotecznego. Niezaprzeczalnym faktem jest, że etyka wpływa na funkcjonowanie biblioteki i, że biblioteka musi uwzględniać ten czynnik, choćby w trosce o swoje dobre imię. Czy jednak rzeczywiście pierwiastek etyczny można odnaleźć w niemal każdym z elementów sponsoringu i fundraisingu oraz w każdym „zakątku” biblioteki? Spróbujemy, jeśli nie udowodnić, to przynajmniej zmierzyć się z tą tezą, wychodząc od teorii, tj. od kilku podstawowych pojęć, od typologii, przedmiotu i podmiotu, poprzez kryteria, a kończąc na praktyce sponsoringu i fundraisingu bibliotecznego. $\mathrm{W}$ tak zwanej praktyce umieściliśmy

1 Zob. P. Ladewig: Katechizm biblioteki. Oprac. i tł. Z. Gębołyś, B. Kwoka. Bydgoszcz 2016, s. 22-26. Informacje biograficzne o Paulu Ladewigu można znaleźć również: A. von Morzé: Ladewig Paul. W: Neue Deutsche Biographie. B. 13, Krell-Laven. Berlin 1982, s. 392-393.

2 P. Ladewig, dz. cyt., s. 132. 
rozważania nad etycznymi aspektami sponsoringu i fundraisingu bibliotecznego. Chcielibyśmy wyjaśnić, jakie wartości i standardy etyczne łączą się $\mathrm{z}$ tymi pojęciami. Interesującym będzie odszukanie problematyki sponsoringu i fundraisingu w kodeksach etyki bibliotecznej i informacyjnej, $\mathrm{w}$ kodeksach etycznych fundraisingu i sponsoringu oraz w wybranej literaturze przedmiotu, tj. publikacjach poświęconych bądź etyce bibliotecznej, bądź sponsoringowi i/lub fundraisingowi bibliotecznemu. Na koniec pragniemy rozważyć, gdzie faktycznie występuje etyczny konflikt interesów pomiędzy biblioteką $\mathrm{z}$ jednej strony a sponsorem/fundraiserem z drugiej strony. Spróbujemy również przywołać kilka mniej lub bardziej spektakularnych przypadków ze styku etyki, biblioteki oraz fundraisingu i sponsoringu.

\section{Stan badań}

Sponsoring i fundraising biblioteczny jest tematem wprawdzie rzadkim, ale obecnym w polskiej literaturze fachowej. Nie budzi on może takiego zainteresowania jak szeroko rozumiana działalność kulturalna czy sport, ale nie można powiedzieć, aby był ignorowany. Do 2015 r. częściej był spotykany jako temat poboczny na marginesie ogólniejszych rozważań nad finansową działalnością bibliotek ${ }^{3}$. Wyjątkiem potwierdzającym tę regułę były artykuły i recenzje na ten temat pióra Zdzisława Gębołysia ${ }^{4}$

3 Finanse $w$ bibliotece. Praktyczny przewodnik dla dyrektorów, kierowników oraz pracowników bibliotek. Zespół autorski pod red. Z. Gębołysia. Warszawa 2008.

4 Z. Gębołyś: Sponsoring i fundraising biblioteczny. W: Vademecum bibliotekarza. Pod red. L. Bilińskiego. Warszawa 2004; Z. Gębołyś: Sponsoring i fundraising w bibliotekach akademickich - z doświadczeń krajowych i zagranicznych. „Fides: Biuletyn Bibliotek Kościelnych” 2010, 1/2(30/31), s. 65-80; Z. Gębołyś: Sponsoring szansq dla biblioteki!? W: Zarzadzanie w organizacjach non-profit. Strategie. Marketing. Red. nauk.: A. Chodyński, M. Huczek, I. Socha. Bielsko-Biała 2001, s. 78-90; Z. Gębołyś: Etyczne rozterki, etyczne dylematy, etyczne zasady polskich bibliotekarzy ( $w$ świetle ankiety). W: Jakość usług w społeczeństwie informacyjnym. Praca zbiorowa pod red. J. Kamińskiej i B. Żołędowskiej-Król. Warszawa 2009, s. 185-193; Z. Gębołyś: Alternatywne źródła finansowania bibliotek szkół wyższych (sponsoring, fundraising, lobbing). W: Biblioteki szkół wyższych w społeczeństwie wiedzy. Uwarunkowania i wybrane zagadnienia. T. 2. Pod red. I. Sochy. Katowice 2010, s. 120-145; Z. Gębołyś: Etyczne dylematy gromadzenia i opracowania zbiorów bibliotecznych. W: Dylematy opracowania. Materiały z V Ogólnopolskiej Konferencji Naukowej zorganizowanej przez Bibliotekę Główna Uniwersytetu Szczecińskiego. Szczecin 18-20 września 2013 r. Pod red. U. Ganakowskiej i M. Różyckiej. Szczecin 2014, s. 6-18. 
oraz nieliczne teksty kilku innych autorów ${ }^{5}$. W 2015 r. pojawiła się książka Dariusza Grygrowskiego pod nieco nienaukowym, zgoła publicystycznym tytułem Biblioteka i pieniądze $e^{6}$, w której jeden z rozdziałów został w całości poświęcony fundraisingowi bibliotecznemu. Tam też umieszczona jest dwustronicowa notatka, w której D. Grygrowski odnosi się, zapewne wskutek braku innego źródła, do rozprawy K. Tekień i J. Iłowieckiej-Tańskiej o etycznym fundraisingu ${ }^{7}$. Właśnie $\mathrm{w}$ takich i podobnych publikacjach należy szukać pytań i odpowiedzi w kwestii etyki sponsoringu i fundraisingu, a także inspiracji do tego tematu. To też dobry powód, aby się zająć tym problemem. Otym, że jest ważny i istotny dowodzi przegląd bibliograficznych baz danych o międzynarodowym zasięgu, jak np. LISA. Ta największa bibliologiczna baza danych rejestruje (stan: 22 czerwca 2017) 1781 rekordów dotyczących fundraisingu bibliotecznego (fundraising and libraries) oraz 271 rekordów dotyczących sponsoringu bibliotecznego (sponsoring and libraries $)^{8}$. Zdecydowanie przeważają publikacje niesamoistne wydawniczo, opublikowane w czasopismach i pracach zbiorowych. Tematyka sponsoringu

5 K. Krakowiak: Sponsoring kultury i sztuki. „Biuletyn EBIB” 2004, nr 9(60). Tryb dostępu: http://ebib.oss.wroc.pl/2004/60/krakowiak.php [23 czerwca 2017]; W. Michnal: Jak Książnica Pomorska w Szczecinie pozyskuje sponsorów. „Bibliotekarz” 1998, nr 4, s. 13-14; M. Sroka: Rola public relations w pozyskiwaniu przyjaciół i sponsorów dla bibliotek akademickich USA. W: Public relations. Red. nauk. M. Kocójowa. Kraków 1994, s. 56-61; Wskazówki dla bibliotek publicznych dotyczące sponsoringu, reklamy i marketingu. Red. A. Filipowicz. „Biuletyn EBIB” 2004, nr 9(60). Tryb dostępu: http://ebib.oss.wroc.pl/2004/60/wskazowki.php [23 czerwca 2017]; B. Śliwińska: Etyka w zawodzie bibliotekarza i pracownika informacji naukowej - wyniki i analiza badań ankietowych przeprowadzonych w środowisku pracowników Biblioteki Głównej Uniwersytetu Opolskiego. Tryb dostępu: http://www.ebib.pl/2008/96/a.php?sliwinska [23 czerwca 2017]; E. Czyżewska: Rozumienie etyki zawodowej w środowisku bibliotekarskim. „Bibliotekarz” 2001, nr 5, s. 2-8; M. Wojciechowska: Wartości etyczne w wybranych aspektach zarządzania i organizacji bibliotek. W: Jakość usług w społeczeństwie informacyjnym. Praca zbiorowa pod red. J. Kamińskiej i B. Żołędowskiej-Król. Warszawa 2009, s. 175-184.

6 Zob. D. Grygrowski: Biblioteki i pieniądze. Warszawa 2015, s. 174-182.

7 Zob. K. Tekień, I. Iłowiecka-Tańska: Etyczny fundraising. W stronę beneficjentów. W: Serca i pieniądze ponad granicami. Ed. J. Mihálik. Bratislava 2012, s. 323-336; A. Klimczuk: Etykajako obszarikontekst standaryzacji działalnościorganizacjipozarzadowych.W:Poradnikstandardównormatywnychdlaorganizacjipozarządowychzpowiatu oleckiego. Fundacja Rozwoju Ziemi Oleckiej. Ed. K. Sztop-Rutkowska. Tryb dostępu: https://ssrn.com/abstract=2740442 [23 czerwca 2017].

8 Library and Information Science Abstract. 
w bibliotece stosunkowo rzadko przybiera formę publikacji książkowej9. Zdecydowanie częściejautorzyksiążek sięgają po temat fundraisingu wbibliotece. Najnowszą, wydaną drukiem w czerwcu 2017 r. publikacją, przedstawiającą stosowanie sponsoringu i/lub fundraisingu w praktyce bibliotecznej, jest praca Adriana Sargeanta i Jena Shanga o wymownym tytule Fundraising principles and practice ${ }^{10}$. Jeden $\mathrm{z}$ podrozdziałów tej na razie niedostępnej w Polsce książki jest poświęcony etyce profesjonalnego fundraisingu. Warto też wspomnieć o dwóch innych publikacjach o charakterze poradnikowym dotyczących fundraisingu w bibliotekach, również wydanych w USA. Pierwsza z nich, nowsza, wydana w 2013 r. pióra Scotta C. Stevensona ${ }^{11}$, druga, Jamesa Swanna, wydana w 2002 r. ${ }^{12}$

Polski wkład w piśmiennictwo dotyczące sponsoringu i fundraisingu bibliotecznego, poza wspomnianymi artykułami jest znikomy. W związku $\mathrm{z}$ czym $\mathrm{w}$ oczekiwaniu na podręcznik sponsoringu $\mathrm{i} / \mathrm{lub}$ fundraisingu bibliotecznego przychodzi sięgać do książek z obszarów pokrewnych lub do ogólniejszych opracowań poświęconych sponsoringowi i fundraisingowi ${ }^{13}$. W 2014 r. wyszedł pierwszy polski poradnik fundraisingu autorstwa Macieja Gnyszki, przedstawiający problematykę fundraisingu i na jej marginesie również sponsoringu, $\mathrm{w}$ sposób popularny i bardzo użytkowy ${ }^{14}$, niezbyt jednak przydatny do tematu niniejszej rozprawy.

W niemieckim obszarze językowym do tej pory nie wydano podobnej publikacji, ale od $2001 \mathrm{r}$. wznawiany jest co kilka lat podręcznik podstaw, strategii i metod fundraisingu, w którym problematyka etyki fundraisingu również jest obecna ${ }^{15}$. Zagadnienia łączące się z fundraisingiem i sponsoringiem można odnaleźć $\mathrm{w}$ rozprawach poświęconych etyce bibliotecznej. Tak się stało w książce, emerytowanej profesor Szkoły Bibliotekarstwa i Informacji Naukowej w Indianopolis, Jean Perer, która w dwóch spośród

9 Sponsorship in libraries. Vol. 1/2. London 1992; Sponsoring für Bibliotheken. Hrsg. R. Busch. Berlin 1997.

10 A. Sargeant, J. Shang: Fundraising principles and practice. Chechester 2017.

11 Zob. S. C. Stevenson: Fundraising for libraries. How to plan profitable special events. Sioux City 2013.

12 Zob. J. Swann: Fundraising for libraries. 25 proven ways to get more money for your library. New York 2002.

13 L. Stecki: Sponsoring. Toruń 2000; J. Polakowska-Kujawa, M. Kujawa: Sponsoring aspekty prawne i gospodarcze. Warszawa 1994; A. Grzegorczyk: Sponsoring kultury. Warszawa 2003; Z. Gębołyś: Sponsoring i fundraising biblioteczny. Warszawa 2004.

14 Zob. M. Gnyszka: Fundraising. Pierwszy polski praktyczny podręcznik. Gliwice 2015.

15 Zob. Fundraising. Handbuch für Grundlagen, Strategien und Methoden. 5 Aufl. Wiesbaden 2016. 
dziewięciu rozdziałów swojej książki zajęła się występującymi w bibliotekach konfliktami o podłożu finansowym oraz filozoficznym ${ }^{16}$.

\section{Teoria sponsoringu i fundraisingu bibliotecznego}

Diabeł jak zwykle tkwi w szczegółach. Takim szczegółem jest określenie, co faktycznie znaczą te pojęcia i, w którym miejscu dochodzi do ich spotkania z biblioteką i etyką. Kluczową, jak się wydaje, kwestią do wyjaśnienia, jest stwierdzenie, jak właściwie rozumiemy „sponsoring” $i$ „fundraising". Od tego zależeć będzie odpowiedź na inne pytanie, czyli kiedy sponsoring/fundraising jest etyczny, a kiedy nie, i co na to wpływa. Według internetowej Encyklopedii Zarządzania sponsoring - to umowa partnerska, w której sponsor przekazuje podmiotowi sponsorowanemu środki konieczne do realizacji jego celów, w zamian za wykorzystanie tkwiącego w nim potencjału komercyjnego, który umożliwia promocję wizerunku przedsiębiorstwa, jego marek czy produktów. Dzięki udziałowi we wspieranej inicjatywie uzyskuje się efekt kojarzenia z tym, co ona sobą reprezentuje, a pozytywny obraz sponsorowanego przenosi się na sponsora. Znak sponsora towarzyszy imprezom lub działaniu sponsorowanych instytucji ${ }^{17}$. Fundraising to planowe, etyczne i skuteczne zbieranie pieniędzy, które mają służyć dobru wspólnemu. Istotą fundraisingu jest budowanie wieloletnich, stabilnych relacji z otoczeniem, tj. darczyńcami, urzędami, sponsorami, członkami oraz pracownikami oraz wolontariuszami organizacji. Termin „fundraising" powstał z połączenia dwóch angielskich słów: fund - fundusze i raising - zbieranie. Oznacza zatem zbieranie funduszy na cele charytatywne oraz publiczne ${ }^{18}$. Sponsorem jest firma lub osoba prywatna zainteresowana promowaniem siebie lub swoich produktów i ponosząca $\mathrm{z}$ tego tytułu określone koszty. Fundraiser to stanowisko osoby, która zajmuje się profesjonalnym pozyskiwaniem funduszy. Potocznie fundraiser określany jest również jako „profesjonalny pośrednik dobra” ${ }^{19}$. Z kolei, jeżeli etykę

16 Zob. J. Preer: Library ethics. Westport 2008.

17 Z. Gębołyś: Sponsoring. Tryb dostępu: https://mfiles.pl/pl/index.php/Sponsoring [23 czerwca 2017]. Zob. też Z. Gębołyś: Sponsoring i fundraising biblioteczny, dz. cyt. , s. 19.

18 Fundraising $-z$ czym to się je? Tryb dostępu: http://inkubatorkultury.szczecin.pl/ news/fundraising-z-czym-to-si\%C4\%99-je/ [23 czerwca 2017]. Zob. też Z. Gębołyś: Alternatywne źródła finansowania bibliotek szkół wyższych (sponsoring, fundraising, lobbing), dz. cyt., s. 120-145.

19 A. Świderska: Zarządzanie działaniami fundraisingowymi. W: Fundraising $w$ działalności organizacji pozarządowych. Red. A. Grzegorczyk. Warszawa 2011, s. 10. 
biblioteczną pojmować będziemy jako zbiór wymogów i standardów moralnych występujących w profesjonalnych relacjach w bibliotece ${ }^{20}$, to łatwo nam przyjdzie stwierdzić, że etyka pojawia się wszędzie tam, gdzie dochodzi do kontaktu pomiędzy biblioteką a sponsorem/fundraiserem, a mówiąc jeszcze bardziej konkretnie, tam, gdzie dochodzi do konfliktu pomiędzy wartościami i standardami etycznymi, podzielanymi przez bibliotekę, a tymi, które podzielają sponsor/fundraiser. Nie mniej ważnym pojęciem w tym kontekście jest konflikt interesu, czyli konflikt pomiędzy interesem prywatnym i publicznym ${ }^{21}$, mówiąc jeszcze ściślej, to wykorzystanie sprawowanej funkcji do prywatnych celów lub nadużycie funkcji publicznej. Jako taki konflikt interesów jest mniej widoczny, mniej spektakularny i znacznie trudniejszy do wychwycenia. Konflikt interesów zachodzący pomiędzy biblioteką a sponsorem/fundraiserem może przejawiać się w różnych formach. Najcięższa postać to łapownictwo, czyli popełnienie czynu korupcyjnego. Łagodniejszą formą jest działanie biblioteki (bibliotekarza) we własnej sprawie, tzn. przyznawanie sobie samemu rzeczy (korzyści, dóbr) w całości lub w części otrzymanych od sponsora/fundraisera. Hybrydalną formą konfliktu interesów jest nieuprawnione wpływanie na przyśpieszenie załatwienia sprawy. Inną formą konfliktu interesów jest nadużywanie pełnionej funkcji publicznej. Sytuacje te mogą występować również w kontaktach biblioteki ze sponsorem/fundraiserem, gdy jedna ze stron w celu osiągnięcia prywatnych celów sięga po niedozwolone środki. Źródłem konfliktu interesów, mogą być, jak formułuje J. Preer, czynniki światopoglądowe, finansowe, polityczne i osobiste ${ }^{22}$. Sytuacjom tym starają się przeciwstawić obie strony, oprócz tworzenia specjalnych regulacji prawnych, poprzez uchwalanie kodeksów etycznych.

\section{Etyka sponsoringu i fundraisingu bibliotecznego - między teorią a praktyką}

W określeniu etycznego wymiaru sponsoringu/fundraisingu bibliotecznego może być pomocne również spojrzenie na to zagadnienie od strony teoretycznej. Myślimy tu o czynnikach współkształtujących oba pojęcia, w szczególności o: przedmiocie, podmiocie, czasie, miejscu i przyczynach

20 Z. Gębołyś: Etyka biblioteczna i informacyjna. W: Bibliotekarstwo. Pod red. A. Tokarskiej. Warszawa 2013, s. 663-678.

21 Konflikt interesów. Czym jest i jak go unikać? Poradnik dla pracowników administracji rzadowej. [Aut. M. Wnuk]. Warszawa 2015.

22 Zob. J. Preer, dz. cyt., s. 133-182. 
ich powstawania. Etyczny wymiar relacji sponsor/fundraiser - biblioteka skupia się przede wszystkim na obu podmiotach, zajmujących w tej relacji, przynajmniej potencjalnie równorzędną pozycję. Faktycznie stroną słabszą jest biblioteka, będąca stroną biorącą (proszącą). Stroną silniejszą, czasami dominującą, jest podmiot dający, czyli sponsor/fundraiser. Faktycznie obie strony potrzebują się wzajemnie, ale tak naprawdę to ciężar etyczny tej relacji spoczywa w większym stopniu na sponsorze/fundraiserze. Etyka sponsora/fundraisera dotyka jego wiarygodności, wizerunku, objawia się w jego udziale w życiu społecznym i politycznym, a nawet w jego życiu prywatnym. Podmiot - biblioteka musi oczywiście również dbać o wizerunek, o prestiż, o polityczne czy społeczne zaangażowanie. Nieetyczność biblioteki wobec sponsora/fundraisera czy odwrotnie, będzie polegać przede wszystkim na niewywiązywaniu się z zawartej umowy, na rozmijaniu się pod względem etycznym deklaracji (misja, wizja) z czynami, wreszcie na niewłaściwym zachowaniu wobec sponsora/fundraisera (grubiaństwo itp.).

Przedmiot sponsoringu/fundraisingu wiąże się $\mathrm{z}$ etycznością bądź nieetycznością $\mathrm{w}$ relacji $\mathrm{z}$ biblioteką w sposób pośredni. Przedmiotem wsparcia ze strony sponsora/fundraisera może być praktycznie wszystko, co łączy się z biblioteką, jej zasoby rzeczowe, sprzęt, aparatura, świadczone w niej lub dla niej usługi, także człowiek, czyli pracownik biblioteki. Biblioteka nie może i nie powinna się zgadzać na spełnianie takich życzeń sponsora/fundraisera, które godziłyby w jej dobre imię, które naruszałyby dobre obyczaje, które obciążałyby wartości patriotyczne czy religijne i które prowadziłyby do waśni na tle religijnym, rasowym, narodowościowym, politycznym. Dość łatwo przychodzi sobie wyobrazić źródła takich konfliktów, tym bardziej, że spotyka się je także w bibliotekach. Byłyby to np. zakup książek, czasopism czy innych dokumentów do biblioteki godzących w te wartości treścią, bądź też osobą autora, wydawcy, dystrybutora. Kwestią, która mogłaby budzić etyczne zastrzeżenia, mogłoby być żądanie wyboru usługodawcy wedle życzeń sponsora/fundraisera, zwłaszcza wtedy, gdy ów usługodawca reprezentowałby odległy od uznawanych i wyznawanych w bibliotece katalog wartości, a jego akceptacja byłaby traktowana jako akceptacja jego świata wartości. Dotyczy to również dostawcy wyposażenia do biblioteki czy osoby prowadzącej imprezę biblioteczną.

Powyższe uwagi dotyczą też miejsca, sposobu i czasu określającego decyzje (zadania), będące wynikiem działań sponsorskich/fundraiserskich. Myślimy zwłaszcza o tych czynach budzących czy mogących budzić kontrowersje. Należałyby do nich na przykład usytuowanie imprezy (poza biblioteką) w miejscach odwiedzanych przez źle prowadzące się towarzystwo, 
czy też $\mathrm{w}$ miejscach zupełnie nie kojarzących się z biblioteką, np. piwiarnia itp. Jeśli chodzi o sposób, to biblioteka, zwłaszcza publiczna, powinna stronić od udziału w zdarzeniach wykorzystywanych do promocji czy też bieżącej walki o zabarwieniu politycznym albo religijnym. Nieetyczne należałoby uznać żądanie sponsora/fundraisera organizowania wydarzeń bibliotecznych o radosnym charakterze $\mathrm{w}$ okresie poprzedzającym święta religijne, łączących się z kontemplacją, smutnymi przeżyciami, np. Zaduszki, Wielki Post.

Pomocnicze znaczenie dla rozważań na temat sponsoringu/fundraisingu bibliotecznego może mieć typologia. Sponsoring/fundraising pośredni lub bezpośredni wynikający ze statusu organizacyjnego biblioteki nie przekłada się wprost na etykę, chyba że istnieją obawy, iż organizator biblioteki może chcieć narzucić jej swoją wolę, nie akceptowaną z pobudek etycznych. Czas trwania sponsoringu/fundraisingu (krótkoterminowy długoterminowy) też nie powinien mieć bezpośredniego przełożenia na etykę, chyba, że obawiamy się, iż w dłuższej perspektywie może dochodzić do wynaturzeń. Zasięg terytorialny sponsoringu/fundraisingu bibliotecznego (międzynarodowy, krajowy, regionalny, lokalny) będziemy łączyć raczej z rodzajem powiązań czy pokrewieństwa między sponsorem/fundraiserem a biblioteką, aniżeli z etyką, aczkolwiek nie można wykluczyć sytuacji, gdy sponsor/fundraiser o międzynarodowym znaczeniu będzie dążył do narzucania bibliotece nieetycznych z jej punktu widzenia rozwiązań.

\section{Etyka sponsoringu i fundraisingu bibliotecznego w świetle kodeksów etycznych}

Zdobywanie środków przez i na rzecz instytucji non-profit, ma już $\mathrm{w}$ Polsce wieloletnią tradycję i utrwaloną markę. Wyrazem tego jest tworzenie i zakładanie towarzystw (stowarzyszeń) stawiających sobie za cel propagowanie idei fundraisingu, ich wspieranie i rozwijanie. Fundraising znalazł się w orbicie zainteresowań i działalności również instytucji społecznych i komercyjnych, doradzających i szkolących, także za odpłatnością, jak uprawiać fundraising. Narodowe stowarzyszenia fundraisingu/ /fundraiserów można spotkać praktyczne w całej Europie, także na kontynencie północnoamerykańskim, w Australii i Oceanii. W Polsce największą organizacją grupującą fundraiserów jest Polskie Stowarzyszenie Fundra- 
isingu (PSF) ${ }^{23}$. Na poziomie międzynarodowym narodowe organizacje jednoczą się pod sztandarem Europejskiego Stowarzyszenia Profesjonalnego Fundraisingu (European Fundraising Association - EFAP) ${ }^{24}$ oraz Międzynarodowego Stowarzyszenia Profesjonalnego Fundraisingu (Association of Fundraising Professionals - AFP) ${ }^{25}$. Stowarzyszenia fundraisingu są czymś w rodzaju pośredników pomiędzy beneficjentem a darczyńcą. Naturalnym reprezentantem środowiska bibliotekarskiego $\mathrm{w}$ popieraniu podobnych dążeń, oprócz samych bibliotek, są związki i organizacje bibliotekarzy i pracowników informacji. Trzecim składnikiem tego układu jest sponsor/fundraiser. Wzajemne dążenia i interesy wszystkich grup, czasami nawet sprzeczne, spotykają się w miejscu, który nazwalibyśmy nieprzekraczalnym progiem. Można rzec obrazowo, tam gdzie kończy się interes jednej grupy, tam zaczyna się interes drugiej grupy. Tworzą go wyznawane $\mathrm{i}$ stosowane $\mathrm{w}$ praktyce przez wszystkich wartości i standardy etyczne. Zwykle są one składnikiem misji, wizji lub strategii działania. W zwartej, skodyfikowanej postaci występują w kodeksach etycznych i deontologicznych.

\section{Sponsoring i fundraising w świetle kodeksów etyki bibliotecznej}

Analiza kodeksów etyki bibliotecznej i informacyjnej wyraźnie pokazuje brak bezpośrednich odniesień do sponsoringu i fundraisingu $\mathrm{w}$ tych dokumentach. Związek pośredni z obiema kwestiami mają oczywiście wartości i standardy etyczne. Wskazane w tabeli wartości i standardy etyczne, mimo różnych kompozycji i ujęcia treści kodeksów, są obecne $\mathrm{w}$ prawie wszystkich kodeksach etyki bibliotecznej i informacyjnej ${ }^{26}$. „Wartość" jest jednym z podstawowych pojęć używanych w etyce, a także często spotykanym w życiu codziennym. Najczęściej spotykane rozumienia wartości etycznej to: rzecz cenna, coś co jest przedmiotem dążenia, preferowany sposób zachowania, kryterium oceniania, a w filozofii pewien abstrakcyjny byt. Ani specjalnych dowodów, ani też uzasadniania nie wymaga

23 Polskie Stowarzyszenie Fundraisingu. Tryb dostępu: http://www.fundraising.org.pl/ [23 czerwca 2017].

24 European Fundraising Association. Tryb dostępu: http://www.efa-net.eu/ [23 czerwca 2017].

25 Association of Fundraising Professionals. Tryb dostępu: https://www.afpnet.org/ [23 czerwca 2017].

26 Kodeksy etyki bibliotekarskiej na świecie. Antologia narodowych kodeksów etycznych. Pod red. Z. Gębołysia i J. Tomaszczyka. Warszawa 2008. 
powiązanie takich elementarnych wartości, jak: bezstronność, obiektywizm czy uprzejmość z zachowaniami i postawami prezentowanymi przez biblioteki i bibliotekarzy w kontaktach ze sponsorami i fundraiserami. Tym łatwiej to przychodzi, iż podzielane są ze względu na uniwersalny i fundamentalny charakter również przez drugą stronę „medalu”.

Tabela 1. Wartości i standardy etyczne w kodeksach etyki bibliotecznej i informacyjnej

\begin{tabular}{|l|l|}
\hline \multicolumn{1}{|c|}{ Wartości etyczne } & \multicolumn{1}{c|}{ Standardy etyczne } \\
\hline 1. Obiektywizm & 1. Konfidencjonalność danych \\
\hline 2. Bezstronność & 2. Sprzeciw wobec cenzury \\
\hline 3. Dyskrecja & 3. Swobodny dostęp do usług i informacji \\
\hline 4. Uprzejmość & 4. Wysoka jakość usług \\
\hline 5. Szacunek & 5. Zakaz dyskryminacji \\
\hline 6. Profesjonalizm & 6. Zakaz prywaty \\
\hline 7. Uczciwość & 7. Zakaz stronniczości \\
\hline & 8. Ochrona praw autorskich \\
\hline & 9. Poszanowanie współpracowników \\
\hline
\end{tabular}

Zródło: Kodeksy etyki bibliotekarskiej na świecie. Antologia narodowych kodeksów etycznych. Pod red. Z. Gębołysia i J. Tomaszczyka. Warszawa 2008.

Standard etyczny to zbiór zasad, którymi kieruje się organizacja, prowadząc działalność, budując dobre relacje wśród pracowników oraz $\mathrm{w}$ kontaktach $\mathrm{z}$ instytucjami współpracującymi, tak z klientami, jak i z dostawcami. Zdecydowana większość standardów etycznych sformułowanych w kodeksach etyki bibliotecznej może stanowić podstawę relacji, w które wchodzi biblioteka ze sponsorami i fundraiserami. Biblioteka deklarując swoje standardy etyczne, wyznacza jednocześnie nieprzekraczalną granicę dla niej, ale i dla sponsora/fundraisera. Może się oczywiście zdarzyć konflikt na tym polu, ale przynajmniej deklaratywnie trudno sobie wyobrazić konflikt etyczny z powodu zapędów cenzorskich sponsora/ /fundraisera, jego sprzeciw wobec wysokiej jakości usług czy swobodnego dostępu do usług. Najczęściej podnoszoną kwestią w relacjach pomiędzy darczyńcami a beneficjentami jest realny lub potencjalny konflikt interesów, wyłaniający się lub mogący się wyłonić w trakcie wykonywania działalności zawodowej. Chodzi tu o przyjmowanie przez bibliotekarza korzyści od firm, przedsiębiorstw czy wydawnictw, księgarń, tj. od wszyst- 
kich tych instytucji, które produkują, sprzedają lub zajmują się dystrybucją materiałów, sprzętu, czy usług, które mogą być nabywane przez zatrudniającą go bibliotekę. Zasadniczo konflikt interesów nie jest łączony z relacjami sponsoringowymi/fundraisingowymi, nie można jednak wykluczyć go również na tym gruncie. Do zasady transparentności w relacjach z rządem, administracją i gospodarką oraz przeciwstawiania się niewłaściwym zachowaniom, korupcji i przestępczości odwołuje się w swym kodeksie IFLA ${ }^{27}$.

\section{Kodeksy etyki fundraisingu i sponsoringu}

Motorem i celem działalności sponsoringowej/fundraisingowej jest zdobycie środków finansowych dla beneficjenta. Gdzie leży jednak granica, której nie można i nie powinno się przekroczyć? Myślimy oczywiście o granicy etycznej, gdyż przekroczenie granicy prawnej to już zadanie dla prokuratora. Odpowiedź na to pytanie można znaleźć w kodeksach etycznych stowarzyszeń i organizacji zajmujących się fundraisingiem. Posiadają je praktycznie wszystkie organizacje tego typu, krajowe i międzynarodowe. Na plan pierwszy wysuwa się oczywiście kodeks zasad i standardów etycznych AFP, w formie Międzynarodowej Deklaracji Zasad Etycznych $w$ Fundraising $u^{28}$. Deklaracja podnosi 5 podstawowych zasad w działalności fundraisera: uczciwość, szacunek, konsekwencja, empatia, przejrzystość. Deklaracja określa również etyczny wymiar odpowiedzialności fundraisera w stosunku do darowizn, do relacji z udziałowcami (darczyńcami, beneficjentami i pracodawcami), odpowiedzialność za wizerunek oraz za rzetelność, jednoznaczność i transparentność w sprawach finansowych. Deklaracja nie zwalnia członków i organizacji ją popierających od przestrzegania kodeksu etycznego własnego stowarzyszenia. Narodowe kodeksy etyczne fundraisingu sformułowały praktycznie wszystkie stowarzyszenia $\mathrm{z}$ tego obszaru. Ich kodeksy etyczne są do siebie bardzo podobne, gdy chodzi o samą kompozycję oraz o warstwę etyczną. Akcentowane są w nich zwykle wartości etyczne oraz reguły postępowania wobec członków, beneficjentów i organizacji. Spójrzmy na trzy tego typu kodeksy.

27 IFLA Code of Ethics for Librarians and other Information Workers. Tryb dostępu: https://www.ifla.org/faife/professional-codes-of-ethics-for-librarians\#iflacodeofethics [23 czerwca 2017].

28 International Statement of Ethical Principles in Fundraising - Translations. Tryb dostępu: http://www.afpnet.org/Ethics/IntlArticleDetail.cfm?ItemNumber=3774 [23 czerwca 2017]. 
Kodeks Etyki i Profesjonalnego Zachowania Instytutu Fundraisingu w Australii (Fundraising Institute Australia) powtarza wartości (zasady) przyjęte przez AFP. Z interesującego nas punktu widzenia, najważniejszą częścią jest rozdział mówiący o profesjonalnym zachowaniu. Kodeks australijski zobowiązuje fundraiserów do jawności względem otrzymywanych darowizn i kosztów, dalej zobowiązuje ich do poszanowania godności i prywatności beneficjentów, do poufności informacji, do identyfikowania się z jej celami i dążeniami ${ }^{29}$.

Ciekawe rozwiązanie pod tym względem zostało przyjęte w Niemczech. Niemiecki Związek Fundraisingu (Deutscher Fundraising Verband), największa niemiecka organizacja, zrzeszająca profesjonalnych i społecznych fundraiserów i sponsorów (1300 członków) uchwaliła trzy dokumenty etyczne, jeden - dla pojedynczych członków, drugi - dla organizacji, a trzeci - dla usługodawców. Są one względem siebie identyczne, zawierają 19-20 standardów, do których przestrzegania są zobowiązani członkowie: godność, prawo, solidarność, zawód, integralność, przejrzystość, fair, dobrowolność, prywatność, ochrona danych, właściwe wykorzystanie środków, doskonalenie zawodowe, dzielenie się wiedzą i doświadczeniem, wynagrodzenie, brak konfliktu interesów podczas przyjmowania korzyści, przestrzeganie zasad wobec osób trzecich, sankcje ${ }^{30}$.

Największą polską organizacją działającą w obszarze fundraisingu jest Polskie Stowarzyszenie Fundraisingu (PSF). Oprócz integracji i reprezentowania środowiska zawodowego jednym $\mathrm{z}$ najważniejszych jego celów jest propagowanie najwyższych standardów etycznych w działalności fundraisingowej. PSF współuczestniczyło w tworzeniu Międzynarodowej Deklaracji Zasad Etycznych ${ }^{31}$, a w 2011 r. podczas I Kongresu Etyki Fundraisingu uchwaliło polską Deklarację Etyczną Fundraisingu. Liczy ona 6 rozdziałów i 26 artykułów, i w zasadzie nie odbiega w treści od dokumentów tego rodzaju. Wyróżnia polski dokument jego struktura, tj. podział na zasady ogólne, zobowiązania etyczne organizacji, fundraiserów, relacje fundraisera $z$ darczyńcami, organizacjami i innymi fundraiserami ${ }^{32}$.

29 Code of ethics and Professional conduct Fundraising Institute Australia. Tryb dostępu:https://www.fia.org.au/pages/priciples-standards-of-fundraising-practice.html [23 czerwca 2017].

30 Deutscher Fundraising Verband. Ethik und Transparenz. Tryb dostępu: http://fundraisingverband.de/verband/ethische-grundsaetze/ethikregeln.html [23 czerwca 2017].

31 Międzynarodowa Deklaracja Zasad Etycznych w Fundraisingu. Tryb dostępu: http:// www.afpnet.org/Ethics/IntlArticleDetail.cfm?ItemNumber=3774 [23 czerwca 2017].

32 Deklaracja Etyczna Fundraisingu. Warszawa 2011. Tryb dostępu: http://www.fundra- 
Warto również zwrócić uwagę na Kartę Praw Donatora (Donor Bill of Right) promowaną również przez AFP, która precyzuje prawa darczyńców $\mathrm{w}$ relacjach $\mathrm{z}$ beneficjentami ${ }^{33}$.

Wartości i standardy etyczne są promowane również przez instytucje zajmujące się sponsoringiem. Przykładem tego jest kodeks międzynarodowy sponsoringu uchwalony przez Międzynarodową Izbę Handlową (ICC) ${ }^{34}$. Kodeks podkreśla między innymi poszanowanie wartości, niewykorzystywanie dzieci i młodzieży, kierowanie się humanitaryzmem i miłosierdziem oraz inne kwestie. Kodeks określa również obowiązki sponsora i sponsorowanego. Do wspomnianego kodeksu nawiązuje polski Kodeks sponsoringu kultury, uchwalony przez Narodowe Centrum Kultury w $2011 \mathrm{r}^{35}$. Wprawdzie w preambule twórcy kodeksu zastrzegają, że nie odnoszą się do innych form współpracy, jak mecenat, patronat medialny czy filantropia korporacyjna, to na jego kartach można znaleźć szereg stwierdzeń, które mogłyby być zastosowane również $\mathrm{w}$ tych obszarach. Kontekst etyczny, oprócz katalogu wyznawanych wartości, zaznaczony został w pkt. VI.3., zakazującym sponsoringu, który mógłby wpływać negatywnie na stan psychiczny, moralność i/lub stosunki rodzinne, a zwłaszcza relacje dzieci z rodzicami.

\section{Etyka sponsoringu i fundraisingu bibliotecznego - między praktyką a teorią}

Sponsoring i fundraising biblioteczny niejedno ma imię. Widać to zarówno $\mathrm{w}$ rozważaniach o charakterze czysto teoretycznym, widać to w tworzeniu dokumentów regulujących i określających postawy i zachowania etyczne. Najpełniej i najwcześniej jest to widoczne w praktyce bibliotecznej. Tym jednak nie będziemy się zajmować nie tylko dlatego, że łatwo popaść $\mathrm{w}$ tani dydaktyzm, w instruktażowy ton, opisując tak zdarzenia etyczne, jak i nieetyczne, jak to ma miejsce $\mathrm{w}$ wielu podręcznikach fundraisingu i sponsoringu. Lepszą drogą wydaje się przeprowadzenie mniej lub bardziej rozległych badań na temat stosowania lub niestosowania fundraisingu i sponsoringu $\mathrm{w}$ bibliotekach, na temat etycznych i nieetycznych

ising.org.pl/0-fundraisingu/etyka/ [23 czerwca 2017].

33 A Donor Bill of Rights. Tryb dostępu: http://www.case.org/Samples_Research_and_ Tools/Principles_of_Practice/Donor_Bill_of_Rights.html [23 czerwca 2017].

34 Sponsorship. Tryb dostępu: http://www.codescentre.com/icc-code/sponsorship.aspx [23 czerwca 2017].

35 Dobre praktyki sponsoringu kultury. Tryb dostępu: http://nck.pl/blog-kultura-sie-liczy/ 316788-dobre-praktyki-sponsoringu-kultury/ [23 czerwca 2017]. 
zachowań i postaw spotykanych $\mathrm{w}$ trakcie prowadzonych działań czy kampanii marketingowych. Żeby obraz był pełniejszy należałoby podobne badania przeprowadzić także wśród fundraiserów (organizacji fundraisingowych), wśród sponsorów oraz darczyńców. Dopiero na tej podstawie dałoby się wywieść jakieś konkretne wnioski i sformułować postulaty. Jak nam się wydaje nie mniej dobrym sposobem $\mathrm{w}$ tym kierunku jest próba określenia miejsc czy punktów, w których dochodzi do etycznych „tarc”, do występowania etycznych dylematów na bazie sponsoringu/fundraisingu bibliotecznego. Problemem podstawowym są powody chęci i niechęci bibliotek wobec udziału w projektach sponsoringowych i fundraisingowych. Trafnie je wyliczają dwie niemieckie autorki Sabine Bachofner i Iris Hoffmann $\mathrm{w}$ swojej pracy dyplomowej nt. fundraisingu w bibliotekach ${ }^{36}$. Nietrudno się zgodzić, że źródeł zaangażowania bibliotek w poszukiwaniu np. pieniędzy poprzez sponsoring/fundraising należy dopatrywać się w skąpości środków finansowych. Gdyby było inaczej, czy biblioteki podejmowałyby działania w tym kierunku? Trudno powiedzieć, warto jednak zapytać te biblioteki, które mają pozytywne doświadczenia w tym zakresie, także od strony etycznej. Ważnym czynnikiem jest wspieranie poprzez sponsoring/ /fundraising bieżącej działalności biblioteki oraz jej dalszego rozwoju. Wśród głównych powodów niechęci wobec sponsoringu/fundraisingu dostrzec możemy zbyt mały personel w stosunku do potrzeb. Niebagatelną przeszkodę przedstawiają zawiłe, często niejasne, ale również niezachęcające do korzystania z pomocy innych przepisy prawne. Pewnie wiele bibliotek przed jakąkolwiek akcją sponsoringową/fundriasingową paraliżuje już na samym początku świadomość olbrzymiej konkurencji zewnętrznej. Strach przed sponsoringiem/fundraisingiem może mieć rzeczywiście „wielkie oczy”. To strach przed złym wypadnięciem, z czym ma związek niska samoocena własnej atrakcyjności, strach przed niekorzystnym, być może też strach przed etycznym wpływem danego sponsora/fundraisera na bibliotekę. Biblioteki stronią od sponsoringu/fundraisingu również dlatego, iż obawiają się, zbyt dużych nakładów i zbyt małego zysku.

36 S. Bachofner, I. Hoffmann: Fundraising in Bibliotheken - ein Desiderat?! Masterarbeit Studiengang Bibliotheks- und Informationsmanagement der Hochschule der Medien Stuttgart. Stuttgart, Januar 2012. Tryb dostępu: https://www.google.pl/ur1 ? $\mathrm{sa}=\mathrm{t} \& \mathrm{rct}=\mathrm{j} \& \mathrm{q}=\&$ esrc $=\mathrm{s} \&$ source $=$ web \&cd=1\&ved=0ahUKEwj2jtS6zsDaAhUGhiwKHfwiBZIQFgguMAA\&url=https\%3A\%2F\%2Fhdms.bsz-bw.de\%2Ffiles\%2F649\%2FFundraising_in_Bibliotheken_MA_Bachofner_Hoffmann_HdM_BIM0912. pdf\&usg=AOvVaw2lt8GgREvGciQ51_N4O92p [23 czerwca 2017]. 
Źródeł obaw i niepewności przed sponsoringiem/fundraisingiem bibliotecznym można się doszukać w „rynku” darczyńców. Jak wiadomo pretendentów do sponsora/fundraisera jest bez liku, w dodatku biblioteki nie są postrzegane jako najbardziej „pożądani partnerzy”. Czynnik etyczny może być ważną monetą przetargową $\mathrm{w}$ pozyskiwaniu sponsora/fundraisera. Biblioteki, jak niewiele innych instytucji publicznych, zasługują na miano neutralnych politycznie oraz tych, które nie wchodzą zbyt często w konflikty natury etycznej. Warto więc może eksponować tę kwestię. Gama instrumentów sponsoringu/fundraisingu jest dość obszerna. Obejmuje listy, maile, imprezy, kontakty osobiste itd. Każdy z tych instrumentów mieści w sobie czy „na sobie” pierwiastek etyczny. Ważną kwestią z pogranicza etyki jest odpowiedzialność za fundraising/sponsoring. Spada ona ze strony biblioteki na inne gremia: kierownictwo biblioteki, kierownictwo działu biblioteki zajmującego się tymi sprawami. Z odpowiedzialnością za programowanie sponsoringu/fundraisingu wiąże się też personalna odpowiedzialność etyczna. Być może największy wpływ na przystąpienie ze strony biblioteki do projektów sponsoringowych/fundraisingowych mają doświadczenia biblioteki. Niebagatelne znaczenie mają $\mathrm{w}$ tym kontekście doświadczenia etyczne. Rzecz w tym, że najtrudniej się o nich dowiedzieć. Nie mają powodów, by chwalić się nimi, ci (biblioteki, darczyńcy, fundraiserzy, sponsorzy), którzy postępują nieetycznie. Przykładów nieetycznych zachowań trzeba szukać, chcąc nie chcąc w Internecie. Bibliotece nie wypada piętnować nieetycznych partnerów sponsoringu/fundraisingu, ale dlaczego nie pójść inną drogą, to znaczy chwalić tych spośród fundraiserów i sponsorów, którzy wyróżniają się pod względem etycznym?

\section{Zamiast zakończenia}

Zaczęliśmy od myśli Ladewiga i na innej myśli Ladewiga pragniemy skończyć: „niedostatecznie dotowana biblioteka nie ma prawa istnieć" ${ }^{37}$. Sprowadzając ją na „etyczne tory”, możemy powiedzieć, że poszukiwanie pieniędzy na funkcjonowanie biblioteki poza naturalnymi źródłami, na przykład drogą sponsoringu lub fundraisingu, jako jedyne wyjście z sytuacji, nie musi, ale może prowadzić do zaistnienia rożnych dylematów etycznych, może też prowokować nieetyczne kazusy. Siedem dylematów etycznych w zakresie "filantropijnego" fundraisingu określił dyrektor The

37 P. Ladewig, dz. cyt., s. 115. 
Hendrickson Institute for Ethical Leadership przy Saint Mary's University of Minnesota. Jak zaznacza, nie powinny być one przeszkodą w zdobywaniu pieniędzy, ale też wszyscy liderzy, organizatorzy organizacji pozarządowych, menedżerzy, fundraiserzy i ofiarodawcy powinni być ich świadomi: 1. Skażone pieniądze - konflikt pomiędzy misją a źródłem pochodzenia funduszy; 2. Rekompensata dla fundraiserów i za fundraising - niedopuszczalność jakiejkolwiek formy rekompensaty; 3 . Prywatność - niezbieranie i nieprzechowywanie informacji o charakterze personalnym oraz nie związanej z fundraisingiem; 4. Zarządzanie - wykorzystanie funduszy zgodnie z wolą darczyńcy; 5. Uczciwość i jawność; 6 . Konflikt interesów - unikanie sytuacji związanych z ryzykiem; 7. Przejawianie się niepoprawności unikanie sytuacji, kierującej na złą drogę $e^{38}$.

Fotografia 1. Robert Morin - dobroczyńca Uniwersytetu i Biblioteki Uniwersyteckiej w New Hampshire

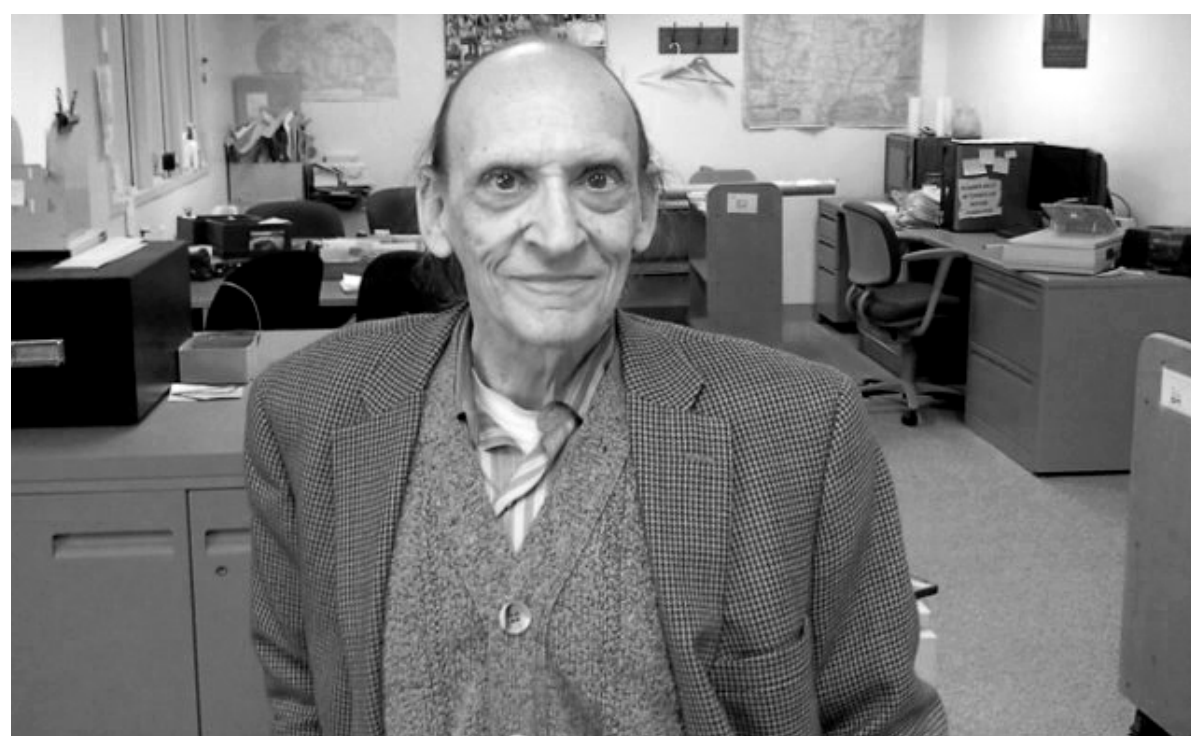

Źródło: A very unusual gentleman' who worked in a university library for nearly 50 years donated his entire estate to the school upon his death. Tryb dostępu: http://www. businessinsider.com/university-of-new-hampshire-librarian-donated-entire-4-million-estate-2016-9? IR=T [23 czerwca 2017].

387 Ethical Dilemmas Facing Nonprofit Organizations. Tryb dostępu: http://nonprofithub.org/human-resources/7-ethical-dilemmas-facing-nonprofit-organizations/ [23 czerwca 2017]. 
Fotografia 2. W. Brett Wilson - niechciany? dobroczyńca Biblioteki Miejskiej w Calgary

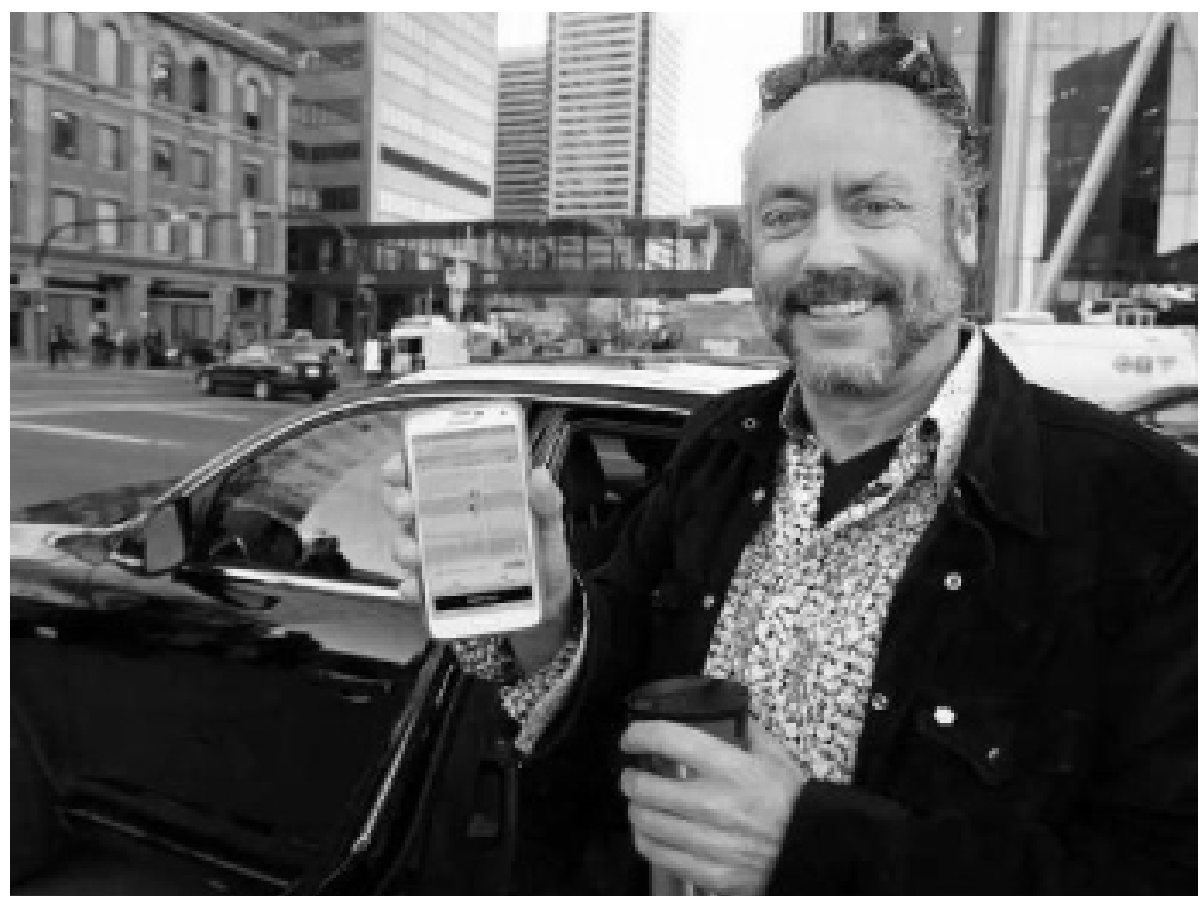

Źródło: Brett Wilson offers $\$ 100 \mathrm{~K}$ library donation if Calgary allows Uber. Tryb dostępu: www.cbc.ca/news/canada/calgary/brett-wilson-100k-library-donation-if-calgary-approves-uber-1.3307222 [23 czerwca 2017].

Częstym problemem w działalności tego rodzaju jest rozmijanie się lub odbieganie podobnych rad czy zapisów, także zawartych w kodeksach etycznych, z rzeczywistością. Jako takie nie mają mocy sprawczej, nie bronią przed nieetycznymi przypadkami, a mówiąc o niebezpieczeństwach, starają się promować etyczne zachowania i postawy. Tych jednych i drugich nie brakuje także w odniesieniu do bibliotek. Podnieśmy dwa bardzo spektakularne, oba z drugiej półkuli. Robert Morin, bibliotekarz z New Hampshire, żyjący więcej niż skromnie, zapisał zaoszczędzone 4 mln dolarów uczelni, $\mathrm{z}$ tego 100 tys. dla budżetu biblioteki ${ }^{39}$.

39100 tysięcy dla biblioteki. Tryb dostępu: http://evascriba.blogspot.com/2016/09/100tysiecy-dla-biblioteki.html; A very unusual gentleman' who worked in a university library for nearly 50 years donated his entire estate to the school upon his death. Tryb dostępu: http://www.businessinsider.com/university-of-new-hampshire-librariandonated-entire-4-million-estate-2016-9? IR=T [23 czerwca 2017]. 
Drugi kazus reprezentuje Brett Wilson, lokalny przedsiębiorca z Calgary, który zaproponował bibliotece miejskiej w Calgary 100 tys. dolarów ${ }^{40}$, warunkując to od decyzji miasta, które wcześniej musiałoby zalegalizować na jej terenie usługę Uber ${ }^{41}$.

Zakończmy po szekspirowsku, przyjąć, czy nie przyjmować pieniędzy (innej pomocy) od sponsora/fundraisera - oto jest pytanie. Oby przy podejmowaniu podobnych decyzji nie zabrakło bibliotekarzom, sponsorom i fundraiserom gotowości do refleksji etycznej.

\section{Bibliografia}

1. 100 tysięcy dla biblioteki. Tryb dostępu: http://evascriba.blogspot.com/2016/ 09/100-tysiecy-dla-biblioteki.html; http://www.businessinsider.com/university-of-new-hampshire-librarian-donated-entire-4-million-estate-2016-9? IR=T [23 czerwca 2017].

2. 7 Ethical Dilemmas Facing Nonprofit Organizations. Tryb dostępu: http:// nonprofithub.org/human-resources/7-ethical-dilemmas-facing-nonprofit-organizations/ [23 czerwca 2017].

3. A Donor Bill of Rights. Tryb dostępu: http://www.case.org/Samples_ Research_and_Tools/Principles_of_Practice/Donor_Bill_of_Rights.html [23 czerwca 2017].

4. A very unusual gentleman' who worked in a university library for nearly 50 years donated his entire estate to the school upon his death. Tryb dostępu: http://www.businessinsider.com/university-of-new-hampshire-librariandonated-entire-4-million-estate-2016-9? IR=T [23 czerwca 2017].

5. Association of Fundraising Professionals. Tryb dostępu: https://www.afpnet. org/ [23 czerwca 2017].

6. Bachofner S., Hoffmann I.: Fundraising in Bibliotheken - ein Desiderat?! Masterarbeit Studiengang Bibliotheks- und Informationsmanagement der Hochschule der Medien Stuttgart. Stuttgart, Januar 2012. Tryb dostępu: https://www.google.pl/url?sa=t\&rct=j\&q=\&esrc=s\&source=web\&cd = 1 \&ved $=0$ ahUKEwj2jtS6zsDaAhUGhiwKHfwiBZIQFgguMAA\&ul=htps\%3A\%2F\%2Fhdms.bsz-bw.de\%2Ffiles\%2F649\%2FFundraising in_Bibliotheken_MA_Bachofner_Hoffmann_HdM_BIM0912.pdf\&usg=AOvVaw2lt8GgREvGciQ51_N4O92p [23 czerwca 2017].

40 Brett Wilson offers $\$ 100$ K library donation if Calgary allows Uber. Tryb dostępu: http:// www.cbc.ca/news/canada/calgary/brett-wilson-100k-library-donation-if-calgaryapproves-uber-1.3307222 [23 czerwca 2017].

41 Uber Technologies Inc. - amerykańskie przedsiębiorstwo, z siedzibą w San Francisco (Kalifornia), twórca aplikacji mobilnej Uber, która służy do zamawiania usług transportu samochodowego poprzez kojarzenie pasażerów z kierowcami korzystającymi $\mathrm{z}$ aplikacji. Usługi firmy Uber są dostępne w wielu miastach świata. 
7. Brett Wilson offers $\$ 100 \mathrm{~K}$ library donation if Calgary allows Uber. Tryb dostępu: http://www.cbc.ca/news/canada/calgary/brett-wilson-100k-library-donation-if-calgary-approves-uber-1.3307222 [23 czerwca 2017].

8. Code of ethics and Professional conduct Fundraising Institute Australia. Tryb dostępu: https://www.fia.org.au/pages/principles-standards-of-fundraising-practice.html [23 czerwca 2017].

9. Czyżewska E.: Rozumienie etyki zawodowej w środowisku bibliotekarskim. „Bibliotekarz” 2001, nr 5, s. 2-8.

10. Deklaracja Etyczna Fundraisingu. Warszawa 2011. Tryb dostępu: http://www. fundraising.org.pl/0-fundraisingu/etyka/ [23 czerwca 2017].

11. Deutscher Fundraising Verband. Ethik und Transparenz. Tryb dostępu: http:// fundraisingverband.de/verband/ethische-grundsaetze/ethikregeln.html [23 czerwca 2017].

12. Dobre praktyki sponsoringu kultury. Tryb dostępu: http://nck.pl/blog-kultura -sie-liczy/316788-dobre-praktyki-sponsoringu-kultury/ [23 czerwca 2017].

13. European Fundraising Association. Tryb dostępu: http://www.efa-net.eu/ [23 czerwca 2017].

14. Finanse $w$ bibliotece. Praktyczny przewodnik dla dyrektorów, kierowników oraz pracowników bibliotek. Zespół autorski pod red. Z. Gębołysia. Warszawa 2008.

15. Fundraising - z czym to się je? Tryb dostępu: http://inkubatorkultury.szczecin. $\mathrm{pl} /$ news/fundraising-z-czym-to-si\%C4\%99-je/ [23 czerwca 2017].

16. Fundraising. Handbuch für Grundlagen, Strategien und Methoden. 5 Aufl. Wiesbaden 2016.

17. Gębołyś Z.: Alternatywne źródła finansowania bibliotek szkół wyższych (sponsoring, fundraising, lobbing). W: Biblioteki szkót wyższych w społeczeństwie wiedzy. Uwarunkowania i wybrane zagadnienia. T. 2. Pod red. I. Sochy. Katowice 2010.

18. Gębołyś Z.: Etyczne dylematy gromadzenia i opracowania zbiorów bibliotecznych. W: Dylematy opracowania. Materiały $z$ V Ogólnopolskiej Konferencji Naukowej zorganizowanej przez Bibliotekę Główną Uniwersytetu Szczecińskiego, Szczecin 18-20 września 2013 r. Pod red. U. Ganakowskiej i M. Różyckiej. Szczecin 2014, s. 6-18.

19. Gębołyś Z.: Etyczne rozterki, etyczne dylematy, etyczne zasady polskich bibliotekarzy ( $w$ świetle ankiety). W: Jakość usług $w$ społeczeństwie informacyjnym. Praca zbiorowa pod red. J. Kamińskiej i B. Żołędowskiej-Król. Warszawa 2009, s. $185-193$.

20. Gębołyś Z.: Etyka biblioteczna i informacyjna. W: Bibliotekarstwo. Pod red. A. Tokarskiej. Warszawa 2013, s. 663-678.

21. Gębołyś Z.: Sponsoring i fundraising biblioteczny. W: Vademecum bibliotekarza. Pod red. L. Bilińskiego. Warszawa 2004.

22. Gębołyś Z.: Sponsoring i fundraising w bibliotekach akademickich $-z$ doświadczeń krajowych i zagranicznych. „Fides: Biuletyn Bibliotek Kościelnych” 2010, $1 / 2(30 / 31)$, s. 65-80.

23. Gębołyś Z.: Sponsoring szansą dla biblioteki!? W: Zarządzanie w organizacjach non-profit. Strategie. Marketing. Red. nauk.: A. Chodyński, M. Huczek, I. Socha. Bielsko-Biała 2001, s. 78-90. 
24. Gębołyś Z.: Sponsoring. Tryb dostępu: https://mfiles.pl/pl/index.php/Sponsoring [23 czerwca 2017].

25. Gnyszka M.: Fundraising. Pierwszy polski praktyczny podręcznik. Gliwice 2015.

26. Grygrowski D.: Biblioteki i pieniadze. Warszawa 2015, s. 174-182.

27. Grzegorczyk A.: Sponsoring kultury. Warszawa 2003.

28. IFLA Code of Ethics for Librarians and other Information Workers. Tryb dostępu: https://www.ifla.org/faife/professional-codes-of-ethics-for-librarians\#iflacodeofethics [23 czerwca 2017].

29. International Statement of Ethical Principles in Fundraising - Translations. Tryb dostępu: http://www.afpnet.org/Ethics/IntlArticleDetail.cfm?ItemNumber $=3774$ [23 czerwca 2017].

30. Klimczuk A.: Etyka jako obszar i kontekst standaryzacji działalności organizacji pozarzadowych. W: Poradnik standardów normatywnych dla organizacji pozarzadowych z powiatu oleckiego. Fundacja Rozwoju Ziemi Oleckiej. Ed. K. Sztop-Rutkowska. Tryb dostępu: https://ssrn.com/abstract=2740442 [23 czerwca 2017].

31. Kodeksy etyki bibliotekarskiej na świecie. Antologia narodowych kodeksów etycznych. Pod red. Z. Gębołysia i J. Tomaszczyka. Warszawa 2008.

32. Konflikt interesów. Czym jest i jak go unikać? Poradnik dla pracowników administracji rządowej. [Aut. M. Wnuk]. Warszawa 2015.

33. Krakowiak K.: Sponsoring kultury i sztuki. „Biuletyn EBIB” 2004, nr 9(60). Tryb dostępu: http://ebib.oss.wroc.pl/2004/60/krakowiak.php [23 czerwca 2017].

34. Ladewig P.: Katechizm biblioteki. Oprac. i tł. Z. Gębołyś, B. Kwoka. Bydgoszcz 2016, s. 22-26.

35. Michnal W.: Jak Książnica Pomorska w Szczecinie pozyskuje sponsorów. „Bibliotekarz” 1998, nr 4, s. 13-14.

36. Międzynarodowa Deklaracja Zasad Etycznych w Fundraisingu. Tryb dostępu: http://www.afpnet.org/Ethics/IntlArticleDetail.cfm?ItemNumber=3774 [23 czerwca 2017].

37. Morzé A. von: Ladewig Paul. W: Neue Deutsche Biographie. Bd.: 13, Krell-Laven. Berlin 1982, s. 392-393.

38. Polakowska-Kujawa J., Kujawa M.: Sponsoring aspekty prawne i gospodarcze. Warszawa 1994.

39. Polskie Stowarzyszenie Fundraisingu. Tryb dostępu: http://www.fundraising. org.pl/ [23 czerwca 2017].

40. Preer J.: Library ethics. Westport 2008.

41. Sargeant A., Shang J.: Fundraising principles and practice. Chechester 2017.

42. Sponsorship in libraries. Vol. 1/2. London 1992.

43. Sponsoring für Bibliotheken. Hrsg. R. Busch. Berlin 1997.

44. Sponsorship. Tryb dostępu: http://www.codescentre.com/icc-code/sponsorship. aspx [23 czerwca 2017].

45. Sroka M.: Rola public relations w pozyskiwaniu przyjaciół $i$ sponsorów dla bibliotek akademickich USA. W: Public relations. Red. nauk. M. Kocójowa. Kraków 1994, s. 56-61.

46. Stecki L.: Sponsoring. Toruń 2000. 
47. Stevenson S. C.: Fundraising for libraries. How to plan profitable special events. Sioux City 2013.

48. Swann J.: Fundraising for libraries. 25 proven ways to get more money for your library. New York 2002.

49. Śliwińska B.: Etyka $w$ zawodzie bibliotekarza i pracownika informacji naukowej - wyniki i analiza badań ankietowych przeprowadzonych $w$ środowisku pracowników Biblioteki Głównej Uniwersytetu Opolskiego. Tryb dostępu: http://www.ebib.pl/2008/96/a.php?sliwinska [23 czerwca 2017].

50. Świderska A.: Zarządzanie działaniami fundraisingowymi. W: Fundraising $w$ działalności organizacji pozarządowych. Red. A. Grzegorczyk. Warszawa 2011, s. 7-47.

51. Tekień K., Iłowiecka-Tańska I.: Etyczny fundraising. W stronę beneficjentów. W: Serca i pieniądze ponad granicami. Ed. J. Mihálik. Bratislava 2012, s. 323-336.

52. Wojciechowska M.: Wartości etyczne w wybranych aspektach zarzadzania i organizacji bibliotek. W: Jakość usług w społeczeństwie informacyjnym. Praca zbiorowa pod red. J. Kamińskiej i B. Żołędowskiej-Król. Warszawa 2009, s. $175-184$.

53. Wskazówki dla bibliotek publicznych dotyczace sponsoringu, reklamy i marketingu. Red. A. Filipowicz. „Biuletyn EBIB” 2004, nr 9(60). Tryb dostępu: http:// ebib.oss.wroc.pl/2004/60/wskazowki.php [23 czerwca 2017]. 